\title{
Subjectivity and Ideological Interpellation: An Investigation of Omar Shahid Hamid's The Spinner's Tale
}

\section{${ }^{1}$ Hina Iqbal $\quad{ }^{2}$ Dr.Muhammad Asif* ${ }^{3}$ Asia Saeed*}

1. Ph.D. Scholar, Department of English Literature, The University of Lahore, Punjab, Pakistan

2. Assistant Professor, Department of English Literature, Government College University, Faisalabad, Punjab, Pakistan

3. Lecturer, Department of English, University of Sahiwal, Punjab, Pakistan

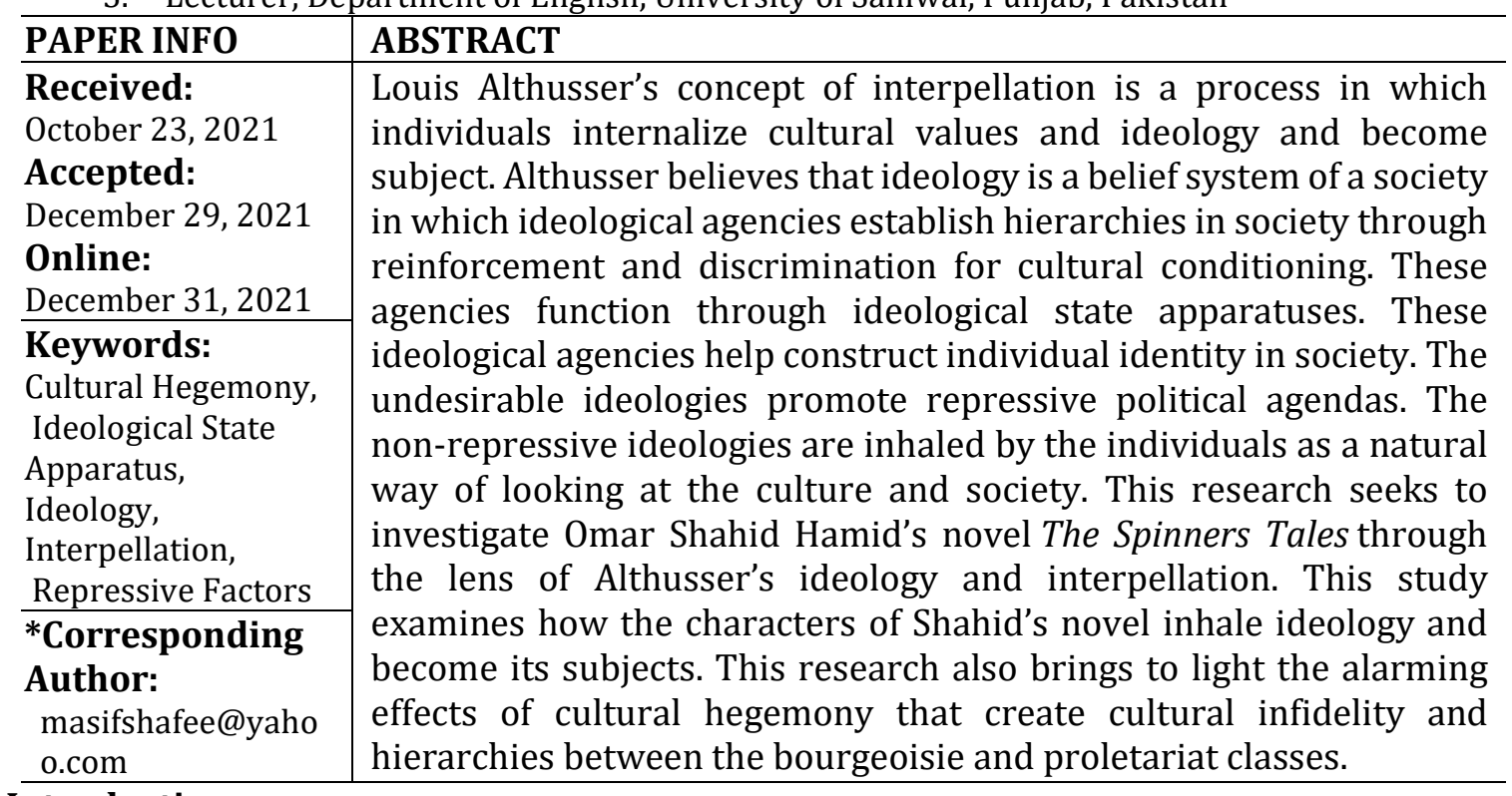

Introduction

Omar Shahid Hamid's novel The Spinner's Tale (2015) shows how ideological state apparatuses interpellate individuals and shape their ideologies and subjectivities, focusing on terrorism and violence that have resulted due to war on terror in Pakistan. During the 'war on terror' the Pakistani state was under attack by the Afghan jihadi activists. The terrorist activists created chaos in the state; both international and national structures of domination were responsible for this destruction. Ideology plays a very important role in the state affairs. Ideology is a set of belief or ideas proposed by the dominated classes of society. Althusser focuses on ideological state apparatuses in which individuals establish imaginary relations with different power structures, submitting to both state on the one hand, and terrorists on the other. The Ideological State Apparatuses interpellate subjects and determine their subjectivity. Omer Shahid Hamid shows how ideology interpellates individuals both physically and morally.

This research aims to locate ideological interpellation subjectivity through the characters of novel within the concept of Althusser's ideological interpellation. This study analyzes the dominant ideology, conflicts and clashes between different state and nonstate groups in Pakistani society through different characters. This research also explores the motivation behind the violence of jihadi activists groups in Pakistan. Narrative inquiry has been employed as methodology to explore ideological constructions and subjectivities. Truth as a subjective construct plays an important role in the inscription of ideology. According to Polkinghome (1988), Karl Popper proposed that "we can at best demonstrate 
the falsity of statements, not their truth. Thus the conclusion of narrative research generally stays open ended" (p.129).

\section{Literature Review}

Marxism is a political, economic and social theory developed by Karl Marx that focuses on the hierarchal conflicts between the ruling class and the subordinate class. Marx believed that this conflict would end in a revolution in which the subordinate class would overthrow the powerful class and control the economy. In a complex social network, the individual realizes that he generates power through hegemonic forces. According to Gramscian analysis, "power resides in ideology" (Woolcock 1985, p. 202). The ruling class takes hold of state power and has it at its disposal in the form of state apparatuses.

Gramsci, an Italian Marxist, participated in the movements of mass proletarian during the First World War. He maintains a strong relationship between power and ideology. He was interested in the empirical and theoretical problems of capitalism. This power is exercised by the bourgeoisie classes through ideology by controlling working class through the institutions of society. Gramsci asserts "philosophy and ideology finally become one and philosophy is revealed as nothing other than a practical instrument for organization and action" (Gramsci, 1971, p.270). He considers ideology as an aspect of "sensationalism". The ideas originate in senses; so the senses can be associated with religion and the belief of "power of spirit". Thus the "science of ideas" shifted to "system of ideas". For Gramsci, "ideology itself must be analyzed historically, in terms of philosophy of praxis, which is called superstructure" (Gramsci, 1971, p. 376).

Althusser developed the concept of ideology in his famous essay "Ideology and The State's Ideological Apparatuses". Althusser asserts that "Ideological state apparatuses" use "ideological" power through the mechanisms of discipline. "An ideology always exists in an apparatus, and its practice, or practices. This existence is material".(Althusser,1971,p.166) Althusser rejects the existence of an independent individual who functions outside the superstructure of ideologies. Martin Carnoy(1986) says that "Ideology recognizes individuals as subjects and subjects them to the "subject" of ideology itself guarantees that everything is "really" so, and that on the condition that the subjects recognize what they are and behave accordingly, everything will be all right"(Carnoy, 1986,p. 92).

Michel Foucault, a French philosopher, borrowed his concept of power from Nietzsche rather than Marx. For Foucault, power is omnipresent; an individual cannot escape from the complex relations made by society. Althusser describes a view of human nature that compels man to inhale some constructed ideology but Foucault tries to locate the modes of power that objectify and transform an individual into the subject. Foucault describes that "this form of power applies itself to immediate everyday life which 
categorizes the individual, marks him by his own individuality, attaches him to his own identity, It is a form of power which makes individuals subjects" (Foucault, 1982, p.212).

Different writers have depicted the concepts of ideology and interpellation in their writings. But I have discussed those writers who strongly present the ideology and interpellation through the characters of their novels. In this research, I have employed narrative inquiry as a research method. Suketu Metha's (2005) in "Maximum City: Bombay Lost and Found" has used Narrative inquiry as a method to present the Bombay city in its different shades and colors. Suketu Mehta presents Bombay city from different angles by taking us into the criminal underworld by depicting different Muslim and Hindu gangs. He also describes the life of bar dancer and Bollywood's strong connection with the mafia. He also throws light on the lives of different poor villagers searching for a better life and ending their lives in misery. "Each person's life is dominated by a central event, which shapes and distorts everything that comes after it and, in retrospect, everything that came before." (Metha, 2005, p.21)

George Orwell (1945) reveals the concept of ideological state apparatus in his novel Animal Farm. The ideological state apparatus represent the smooth power of the ruling class which they use to exploit the other classes of state. In Animal Farm most of the animal characters were exploited by the powerful group of pigs. They also try to manipulate and control the animals to bring a change in their state. The first alteration occurred when pigs entered the farm and started behaving like humans. They adopted human behavior and started sleeping in bed. Squealer play a very important role in the novel to constitute seven commandments to discriminate the pigs by creating the main legislative principle of the farm that "all animals are equal but some animals are more equal than others"(Orwell,1945,p.149). So the state works as an ideological apparatus in Animal Farm for the other animals where the other animals were hegemonized by the ruling power of pigs. So the other animals inhale the superiority of pigs and become a subject.

Similarly, Margate Atwood (1985) in her novel The Handmaid Tale reveals the theme of educational ISA; the education system of different public and private schools that govern the students' ideology. To Althusser, the most important ideological state apparatus is educational ISA, through which students develop good behavior and learn certain rule orders that enforce their inferiority. In The Handmaid's Tale, women of Gilead society are forced to learn the lessons of sexual morality and child bearing at specific Re-education Centers. "When we think of the past it's the beautiful things we pick out. We want to believe it was all like that."(Atwood, 1998,p.232) The Handmaids were considered inferior to their Aunts (teachers) whose jobs were to train the maids and transfer the ideology of the state in the maids unconsciously. It was taught to them that as a woman, their position became more ordinary with time. If they will try to go against the law and show disobedience they will be punished. It was also restricted for handmaids to read books because books will give 
them the idea to stand at once against the repressive society, which Gilead society cannot afford that time, so in Gilead, all the educational tools were restricted.

Omar Shahid Hamid has written two novels; his first novel The Prisoner, starts with the kidnapping of an American journalist named Friedland by a jihadi group. The picture Shahid Hamid paints about Karachi's politicians, police, and religious leaders is quite depressing when in the novel, the character D'Souza notes that to become an optimist is the ultimate sin. D'Souza says about intelligence officer Major Rommel that it is very difficult for an honorable officer to live in such a dishonorable world. The same thing is applied to many police officers' characters in the novel. There were certainly no heroes but they show commitment and bravery against the corrupted, brutal system. Ideology is a concept that making power relations visible in society. Michael Freeden presents a novel approach to ideologies through examining their conceptual morphology. He says,"[ideology] is a structural arrangement that attributes decontested meanings to a range of mutually defining political concepts" (Freeden 2003) .

In her views about The Spinner's Tale, Mita Ghose (2015) writes that this Pakistani novel fascinates her. From the experience of 'other' we are surprised to know a world which is disturbingly familiar to our 'own'. As far as social hierarchies, corruption and social injustice are concerned the outcomes are distressingly similar on both sides of the border; disappointment, violation and growing radicalization of individuals unleashes the terrorism and epidemic of fear of death. Ghose says that Hamid depicted the militant's world and political forces that transform common people into extremist jihadis.

In The Spinner's Tale Shahid Hamid presents violence through the character of Sufis. Hamid had a vast experience of working as police offer in different cities at difficult times, fighting criminal and terrorists of various types. He had personal experience of handling terrorists. Through this novel, Hamid tries to throw light on the lives of top jihadi militants of Pakistan. By creating the character of a dangerous extremist; he provides an insight to the reader about what pushes the people to adopt a path of destruction. Ausi's past letters to Eddy show the economic and social injustice of a socially corrupt society. State plays an important role of active agent in creating division among the masses; this division of masses develops the domination of elite class over oppressed proletariat as Newman says that the state "perpetuate rather than resolve the contradictions in capitalist society" (p.17). To exercise individual sovereignty, Ausi joins a political party and enjoys the authority and power as a political worker.

This discussion so far highlights the links between ideology and interpellation. Both these concepts can be presented through the different characters of the novel The Spinner's Tale. This novel portrayed social and economic injustices that force people to stand up and take arms against the state authority. The Spinner's Tale highlights the violent resistance against the state through the main character of Ausi. This research analyzes the novel The 
Spinner's Tale (2015) by Omar Shahid Hamid from the perspective of Althusser's ideology and interpellation that individual interpellates ideology as subjects. For further explanation, I will discuss Althusser's theory of ideology in detail.

\section{Theoretical Framework}

The theoretical framework that I have employed to the primary text The Spinner's Tale, is ideology and interpellation elucidated by Louis Althusser. Hamid's novel deals with the resistance of common people against the anarchy of state institutions that are called state apparatuses that force middle-class man Ausi to become a religious extremist and terrorist. In the novel, the jihadi groups also motivated the characters to interpellate their ideology. In this chapter, I have discussed Althusser's theoretical views in detail. In this qualitative research, I have also discussed the research method employed in the analysis of the novel.

In her book Research Methods for English Studies, Gabriele Griffen (2013) mentions that research methods offer us exact tools to conduct our research with the help of a specific research methodology (p. 3). This research aims to investigate Omar Shahid Hamid's novel The Spinner's Tale through the characters who interpellate as the subject by the authoritative ideology of society; for this purpose, I have chosen narrative inquiry as a research method.

The narrative inquiry includes personal and social stories of characters. It contributes to research by framing the study of human experiences. Narrative inquiry illuminates the complex problems of societies by unfolding the complicated stories of characters and their relationships to society. Narrative inquiry is the human-centered method that analyses the life story of a person. It evaluates the life events critically and reveals a detailed holistic view. Life stories reflect the writer's experience; it gives powerful insight into our understanding; these stories are reshaped, developed, and retold informally. This research method can be related to my research because, in this novel, Hamid narrates the life story of Sheikh Ahmed Uzair Sufi as Ausi through past incidents of his life, which are in the form of letters that Ausi wrote to his friend Eddy. Through narratives, we can discover new meanings by assimilating life experiences into a narrative schema; the connectedness of a story as it moves within time is the source of transfer of knowledge. So Shahid Hamid used the narrative inquiry research method to explore the life history of Ausi and depicted it in the form of a novel.

This research focuses on the representations of characters as subjects in the novel in the ideological context. According to Marxist theory, ideology is a misrepresentation of the world to ourselves. Marxists classifies society into two classes, the ruling class and the working class or the bourgeoisie and the proletariat; this discrimination in society created 
hegemonic hierarchies which is the base of the superstructure of society. For Marxists, ideology is not only a set of beliefs or assumptions, but it makes us realize that the ways of looking at ourselves and the world are natural. Marxist philosopher Louis Althusser (19181990) writes in his first thesis that "ideology represents the imaginary relationship of individuals to their real conditions of existence"(p.18). So ideology distorts our views and beliefs about truth.

Althusser's notion of ideology is very much similar to Antonio Gramsci's concept of "hegemony". Gramsci presents in contrast 'rule' that is the political control that uses force whenever necessary and hegemony is a social process that has a dominant meaning and can be abstracted as a world view. Hegemony is related to culture in a general sense, while ideology is a particular phenomenon related to the state. .Hegemony is an internalized process of social control; the natural way of looking at things as Gramsci calls hegemony "ruling by consent".

Althusser describes in his second thesis the connection between ideology and social society; he says ideology works through different state apparatuses which he called 'ideological State Apparatuses'. These apparatuses have their sub-ideology and all these apparatuses are subjects to the ruling ideology. In his essay 'Ideological State Apparatus' Althusser develops the relationship between individual and subject and maintains a procedure of subject-hood in which he describes the process of interpellation that leads individuals towards the subject. Althusser writes, "All ideology hails or interpellates concrete individuals as concrete subjects, by the functioning category of subject" (p.173). When individuals are trying to act according to the rules of ideology, they are turned into subjects of that ideology and then interpellation occurs when individuals are hailed directly by ideology.

Althusser's theory of ideology and interpellation helps me to study how the characters of The Spinner's Tale interpellate the ideology of jihadi groups and act as subjects against Pakistani society. Religious extremists, with their magnetic personalities, play with the minds of innocent people who inhale their ideology and transform into jihadi activists. So it can be said that both these concepts ideology and interpellation are quite relevant to the novel The Spinner's Tale, as most of the characters try to resist the state ideology but could not achieve their goal. Despite the theoretical framework of Althusser's ideology and interpellation, this research further analyzes through the research method of narrative inquiry.

\section{Discussion and Analysis}

The Spinner's Tale (2015) focuses on the construction of subjectivity of the individuals who hail from different segments of the society. The main theme of the novel is terrorism. Shahid focuses on the structures that produce criminals and terrorists, and 
further shows how terrorists terrorize society bring untold misery to the people. This novel also focuses the life history of a common man Ausi who becomes a religious extremist and joins the jihadi group as an activist just after the death of his mother. This research focuses on Ausi's transformation through interpellating influence of religion, rendering him a jihadi subject.

The author of this novel is the working officer of the Police Service of Pakistan (PSP) that's why he has a deep insight regarding the state matters of Pakistan and its subordinate apparatuses. The Spinner's Tale opens with the police custody of jihadi terrorist Sheikh Ahmed Uzair Sufi (Ausi) in Karachi, who is taken from the jail to the animal husbandry school. The responsibility of his security was given to Omar Abbasi, a police officer who also tries to reveal the past of Ausi through his letters which Ausi writes to his childhood friend Eddy. According to Althusser, the state apparatuses play a significant role in forming the ideology of a person. The School where Ausi studied was also responsible for the transformation of Ausi, from a common man to a jihadi activist by creating discrimination among the students of different social classes as Hamid says in the novel about Ausi "wearing the uniform of the most prestigious and anglicized educational institutions in the country..... have become the bearded, turbaned decapitator of a pregnant woman" (p.14). He gets admission in The School due to a scholarship as his father was a government officer, so there was a considerable difference between his background and other elitist students. So there was a kind of alienation between him and his class fellows that affected his later life. According to Althusser, the state works as a machine of repression that ensures the ruling classes of their domination over the proletariat by making them subject through the process of exploitation or capitalism.

In the novel, Ausi's past letters are the source of narration between the writer and the reader. These past letters witness the economic and social injustices that he has to bear because of the corrupted society. The state becomes an active agent in perpetuating the division among the masses as Ausi says in the novel: "some politically connected colleague of my father's had the Jamshed Road house allotted to himself"( p.75). When his father tries to go against the decision, they send the police there and they have told to clear that place in a week. So the political elite class threatens the working class by using police force to subjugate the lower class. Althusser examines the subjection of the individuals through prevailing ruling class ideologies. These individuals know about their subjugation under capitalist systems. They assume their destiny as a natural process and remold themselves as part of the system called interpellation . In order to exercise individual sovereignty, Ausi joins a political party and enjoys his position "the backing of the largest political organization in the city" (Hamid); this is what Althusser calls "ideology interpellates us as subjects". 
The whole story of Ausi is narrated through the letters of Ausi, so that's why I have chosen narrative inquiry as a research method. These letters provide a gateway to the past and constitute a path to get himself out of prison by misleading SP Omar. According to Carr (1986), "narrative is not related to short-term experiences but narrates longer events and human experiences. In narrative inquiry, the actions of life and historical existence are structured narratively. In narrative inquire we can experience individuals' past and present living as it is a way of being and dealing with time". So The Spinners Tale also depicts the past and present experiences of Ausi's life; it also reveals his journey of inhaling the process of the jihadi.

After the death of Sohail, Ausi decides to protest against the brutal encounter but the principal was rejected his proposal, so Ausi uses violence as a tool by putting a gun to the principal's head until he permits Ausi to do anything that he wants. Sohail's sister Kiran bears sexual exploitation and becomes a prostitute because she could not resist political authority; Ausi considers himself responsible for this. After the death of his mother, there was no room for Ausi to shelter, and his personality was shattered into pieces and he joins a religious jihadi group as an activist by forcing the Sheikh Saad in Kossovo. Althusser words, "the individual is interpellated as a free subject by submitting his will to the commandments to accept his subjection; in this process, all the gestures and actions of his subjection are all by himself "(Lenin and philosophy).

The Sheikh (leader) of the organization tries to manipulate Ausi's aggression against the country's social institutions, and he succeeded in his plan by trapping Ausi in the name of religion. Sheikh Saad says in the novel that Ausi has lost his true path as Sheikh says in the novel to Ausi, "I am here to help you find your path (p.161). He motivates Ausi to utilize his abilities to destroy the oppressive authorities by choosing the true path for himself, which he calls a "path of resistance". The Sheik narrates several stories to convince Ausi for jihad as "in Bosnia where all the men were murdered by the Serbs and the women and children were either raped or sold into slavery" (p. 162). The Sheikh invoked him by saying that "all of these things are happening to good people because they are Muslim. Islam is under attack" (Hamid, p.165). For Ausi, joining the organization was articulating his passion for resistance to dismantle the state authority. So Ausi joins the jihadi organization and becomes an extremist religious activist by inhaling their religious ideology.

Althusser asserts individuals act unconsciously according to the ruling class and their prevailing ideology. They act according to the rules of the authoritative system and participate in the interpellation or hailing process to obtain dominant ideology. Through this process the subject realizes his or her relation to reality and confirms his or her ideological position in society. The same is the case with Ausi; after joining the jihadi organization he rejects the position of Osama Bin Laden as an authoritative leader by saying that he was a hypocrite. His rejection of Bin Laden shows his "anger and defiance for authority" (p.181). So Ausi also wants to establish a strong position in the jihadi group. 
While in Pakistani prison, Ausi plays with the minds of people and attempts to brainwash the guard skillfully that he was ready to take his own life through suicide bombing for Ausi, as Hamid writes in novel, "the man was willing to take his own life, as well as the lives of dozens of his own colleagues whom he had known for years, just to get the Sheikh out of prison" (p.19). Ausi's successful attempt to brainwash the guard in prison signifies that he was not ready to bow down before the state authority in any case. Ausi considers Osama Bin Laden as an American agent because his plan of 9/11 seemed to be worked in favor of America, not in Taliban. The incident of the destruction of Twin Tower 9/11 proves to be disastrous for Ausi's revolutionary cause because Taliban were identified as the enemy of the West and both U.S and Pakistani force starts working together against Taliban that created terror and chaos in Pakistani state.

Althusser's concept of ideological state apparatus is very much present in the novel when the state establishes its authority through different state apparatuses. Omar Abbasi's investigation discovers more about the past of Ausi that depicts the state repression implemented on his family when the police arrest Rameez (Ausi's older brother) to investigate Ausi's crime it reveals that because of these crucial investigations, Rameez become mentally unstable and they break all the bones of his hand. Ausi's interpellation as subject to the ideology of jihadi groups, provide repressive state apparatuses an excuse to commit violence against the innocent citizens. Through the interpellation process, Ausi transforms into a cruel monster; he was fascinated with the violence, and his desire to use it on other people shows his anarchist personality by naming this violence as resistance against the corrupted state. He internalizes violence as a defense mechanism to show his authority and power to other. At the beginning of the novel, he brutally murders an international journalist Rachel Boyd, a pregnant woman only to get media attention as "prominence given by the media and the Arabs and Al-Qaeda irks him" (p. 264).

Similarly killing his best friend is ultimately a violated act. So we can say that Ausi uses violence as an effective tool against state authority but this violence also brings devastating effects on the society. According to Althusser in a modern capitalist society, the process of individual's interpellation occurs by subjected to ideological masses called ideological state apparatuses and repressive state apparatuses that play a vital role in this process.

The whole story of Ausi's life is narrated through the letters found by police officer Omar Abbasi. At the end of the novel, it reveals that it was the plan of Ausi to mislead the police towards Eddy to escape him from interrogation. These letters were planted by Ausi himself and not from Eddy. However, these letters are false; not depicting the real stories, but Omar Abbasi finds the truth about Ausi from these letters. According to Dyson and Genishi (1994), in narrative inquiry, "stories help to evaluate and integrate the tensions 
inherent in experience; the past with the present, the fictional with the real, the official with unofficial. They help us to transform the present and shape the future" (p.242-243).

All the history of Ausi's life narrates through these letters, so these letters are very important and guide the police officer to inquire about the matter. So in this research narrative inquiry proves to be a very relevant research method to find out the whereabouts of Ausi.

\section{Conclusion}

The Spinner's Tale shows that both ISAs and RSAs play important role in constructing individual identities both passive and negative. RSAs usually prove counterproductive and produce dangerous subjects who sometimes become criminals and terrorists. Ideology usually supports status quo and serves the interests of institutions, the rich and the powerful. Jihadi outfits use religion to indoctrinate individuals and turn them into fanatics. This novel allows us to investigate the nature of terrorist violence in a more elaborate manner. In the novel, the aristocratic class tries to suppress the lower classes by using state apparatuses to act against ordinary people. Sheikh Ahmed Uzair, the main character of the novel, interpellates the ideology of religious jihadi group as a subject and involves violent activities against the state. He enjoys the power and authority as a terrorist, which he hails as a subject by joining the jihadi organization. But in the end, he realized that organization had used him just to gain its objectives of terrorism against the state of Pakistan. He became a monster and tried to destroy the world, but by doing these terrible acts of terrorism, he destroys his own life and destroys the lives of other people who were related to him. He also tries to misguide police from his letters and makes a plan of escape from the jail. This research also highlights that Althusser's theory of ideology and interpellation is connected with Ausi's interpellation of ideology. It is also related to the fact that the social formation of a state is a complex phenomenon; it is a set of the relation between mutually interacting practices which are not determined by the individuals; rather, these practices determined the lives of individuals. Therefore, free and independent subject is considered vague because no free and self-autonomous subject exists in society. The novel is the best presentation of Althusser's model of ideology and interpellation and can be further studied with the help of narrative inquiry 


\section{References}

Althusser, L. (2006). Lenin and philosophy and other essays. Aakar Books.

Althusser,L.(1971). Ideology and ideological state apparatuses. Lenin and philosophy and other essays. Trans. Ben Brewster. New York: Monthly Review Press 1270186.

Atwood, M. (1998). The Handmaid's Tale, Toronto: McClelland \& Stewart

Carnoy, M., \& Levin, H. M. (1986). Educational reform and class conflict. Journal of Education, 168(1), 35-46

Carr, D. (1991). Time, narrative, and history. Indiana University Press

Dyson, A. H., \& Genishi, C. (1994). The Need for Story: Cultural Diversity in Classroom and Community. National Council of Teachers of English.

Foucault, M. (1982). The subject and power. Critical inquiry, 8(4), 777-795

Freeden M (2003). Ideology: A Very Short Introduction. Oxford: Oxford University Press. SCIO: Revista de Filosofía, (9), 169-172

Gramsci, A. (1971). Selections from the prison notebooks, Quintin Hoare and Geoffrey Nowell Smith

Griffin, G. (2013) Research methods for english studies. Edinburgh University Press

Mehta, S. (2005). Maximum City: Bombay Lost and Found (Paperback). Penguin books

Newman, E. (2011). A human security peace-building agenda. Third World Quarterly, 32(10), 1737-1756

Orwell,G.(2013). Animal Farm. London Penguin Classic

Polkinghorne, D. E. (1988). Narrative knowing and the human sciences. Suny Press

Woolcock, J. A. (1985). Politics, ideology and hegemony in Gramsci's theory. Social and Economic Studies, 199-210. 